\title{
Starch and dextrose at 2 levels of rumen-degradable protein in iso-nitrogenous diets: Effects on lactation performance, ruminal measurements, methane emission, digestibility, and nitrogen balance of dairy cows
}

\author{
F. Sun, ${ }^{1}$ M. J. Aguerre, ${ }^{2}$ and M. A. Wattiaux ${ }^{1 *}$ \\ ${ }^{1}$ Department of Dairy Science, University of Wisconsin-Madison, Madison 53706 \\ ${ }^{2}$ Department of Animal and Veterinary Sciences, Clemson University, Clemson, SC 29634
}

\section{ABSTRACT}

Our objectives were to determine the effects of readily rumen-available carbohydrate source (refined starch vs. dextrose), the level of rumen-degradable protein (RDP), and their interaction on lactation performance, ruminal measurements, enteric methane $\left(\mathrm{CH}_{4}\right)$ emission, nutrient digestibility, and nitrogen $(\mathrm{N})$ balance in lactating dairy cows. Eighteen mid-lactation multiparous Holstein cows were used in this split-plot study. The main plots were created by randomly assigning 9 cows to diets of 11 or $9 \%$ RDP obtained by altering the percentage of soybean meal, expeller soybean meal, and blood meal in the diet. All diets included 16.4\% crude protein. In the subplots, the effects of $0: 10,5: 5$, and 10:0 refined starch:dextrose ratio (\% of dietary dry matter) were determined in three $3 \times 3$ Latin squares by randomly assigning the 9 cows in each RDP level into squares. Each period lasted 4 wk, with the last 2 wk allotted for sample collection. Carbohydrate source $\times$ RDP level interaction tended to influence dry matter intake (DMI), the concentration of urinary $\mathrm{N}$, and urinary urea-N. Replacing refined starch with dextrose increased DMI, the molar percentage of ruminal butyrate and valerate, daily $\mathrm{CH}_{4}$ production $(\mathrm{g} / \mathrm{d})$, and fecal $\mathrm{N}$ and decreased the molar percentage of ruminal branched-chain volatile fatty acids, feed efficiency (fatand protein-corrected milk/DMI), and $\mathrm{N}$ use efficiency (milk N/intake $\mathrm{N}$ ) but did not influence nutrient digestibility. Enteric $\mathrm{CH}_{4}$ production was negatively related to the molar percentage of ruminal propionate but positively related to the molar percentage of ruminal butyrate. Treatments did not influence milk production responses, but cows fed 9\% RDP diets had lower ruminal ammonia concentration (7.2 vs. $12.3 \mathrm{mg} / \mathrm{dL})$ and tended to excrete less urinary purine derivatives (428

Received May 10, 2018.

Accepted November 5, 2018.

${ }^{*}$ Corresponding author: wattiaux@wisc.edu vs. $493 \mathrm{mmol} / \mathrm{d}$ ) compared with cows fed 11\% RDP diets, suggesting lower ruminal synthesis of microbial protein. Reducing the level of RDP in iso-nitrogenous diets had no effect on nutrient apparent total-tract digestibility, manure excretion and composition, $\mathrm{N}$ balance, and $\mathrm{CH}_{4}$ production. In this study, treatments did not affect yield (20.0 g of $\mathrm{CH}_{4} / \mathrm{kg}$ of DMI) or intensity (13.1 $\mathrm{g}$ of $\mathrm{CH}_{4} / \mathrm{kg}$ of fat- and protein-corrected milk), but methane production ( $\mathrm{g}$ of $\mathrm{CH}_{4} / \mathrm{d}$ ) was $7.0 \%$ lower and $\mathrm{N}$ use efficiency (conversion of intake $\mathrm{N}$ into milk protein) was $7.8 \%$ higher for cows fed a diet of $28.1 \%$ starch and $4.6 \%$ water-soluble carbohydrate compared with diets with lower starch and higher water-soluble carbohydrate contents.

Key words: greenhouse gas, diurnal enteric methane, digestion, metabolism, nitrogen use efficiency

\section{INTRODUCTION}

There is uncertainty in the literature about the respective contribution of various dietary carbohydrate sources to daily enteric methane $\left(\mathrm{CH}_{4}\right)$ emission, referred to herein as $\mathrm{CH}_{4}$ production $(\mathrm{g} / \mathrm{d})$, from dairy cows. The stoichiometry of carbohydrate fermentation indicates that ruminal propionate production reduces the availability of $\mathrm{H}_{2}$ for $\mathrm{CH}_{4}$ formation, whereas acetate and butyrate production enhances the availability of $\mathrm{H}_{2}$ for $\mathrm{CH}_{4}$ formation (McAllister et al., 1996). Although dietary cell wall carbohydrates are major contributors of acetate, butyrate, and $\mathrm{CH}_{4}$ formation during ruminal fermentation (Moe and Tyrrell, 1979), NFC sources can also affect $\mathrm{CH}_{4}$ production. For example, Hindrichsen et al. (2005) reported greater $\mathrm{CH}_{4}$ production $(\mathrm{g} / \mathrm{d}$ ) and intensity $(\mathrm{g} / \mathrm{kg}$ of $\mathrm{DMI})$ and molar percentage of butyrate in ruminal VFA when feeding diets high in simple sugar compared with diets high in starch. These results, however, were obtained using a variety of feed ingredients and thus may have been confounded by changes in other dietary chemical components. Furthermore, ruminal methanogens responsible for enteric 
$\mathrm{CH}_{4}$ formation utilize ammonia as their primary nitrogen $(\mathrm{N})$ source for assimilation into microbial protein (Jarrell and Kalmokoff, 1988; NRC, 2001). Ammonia is mainly produced from the breakdown of RDP, and limited supply of RDP may have negative effects on microbial protein supply, ruminal fiber fermentation, DMI, and milk production (NRC, 2001; Kalscheur et al., 2006). Thus, it is reasonable to expect that limiting RDP level may also affect enteric $\mathrm{CH}_{4}$ production. Therefore, to unambiguously ascertain the effects of the source of NFC and RDP on enteric $\mathrm{CH}_{4}$ production, we designed treatments with varying proportions of refined (pure) starch and dextrose in diets similar in NFC, NDF, ether extract, and CP but differing in RDP concentration. Our main hypothesis was that replacing starch with dextrose in the diet increases $\mathrm{CH}_{4}$ production and alters the molar percentage of VFA. Our second hypothesis was that reducing RDP from $11 \%$ to approximately $9 \%$ of ration DM reduces $\mathrm{CH}_{4}$ production but has also a negative effect on fiber fermentation, DMI, and milk performance. Our third and auxiliary hypothesis was related to whether the effects of NFC source depend on the level of RDP, especially regarding $\mathrm{CH}_{4}$ production. Thus, our objectives were to quantify the effects of replacing refined starch with dextrose on lactation performance, enteric $\mathrm{CH}_{4}$ production, apparent nutrient digestibility, and $\mathrm{N}$ balance in lactating dairy cows and to determine whether the responses were influenced by the levels of dietary RDP or the interaction between source of NFC and level of RDP. Last, we investigated the change in rate of $\mathrm{CH}_{4}$ emission relative to feeding time.

\section{MATERIALS AND METHODS}

This experiment was conducted at the Dairy Cattle Center of the University of Wisconsin-Madison. The use and care of animals was approved by the University of Wisconsin-Madison Institutional Animal Care and Use Committee.

\section{Cows, Experimental Design, and Dietary Treatments}

In the cow selection phase of the study, a group of 24 multiparous Holstein dairy cows housed in tiestalls were adapted to the GreenFeed unit (C-Lock Inc., Rapid City, SD) that quantifies $\mathrm{CH}_{4}$ production with minimal disturbance (Dorich et al., 2015). Adaptation was measured once daily for $7 \mathrm{~d}$ with a score (on a scale of 1 to 5) reflecting a cow's willingness to move her head forward and keep it in the hooded trough area of the GreenFeed unit when enticed with small amounts of concentrates offered over a 5-min period. The 18 cows with the best adaptation score were selected to participate in the study. These cows (mean $\pm \mathrm{SD}$ ) were at $3.0 \pm 0.6$ parity at the beginning of the study. All cows were injected with $500 \mathrm{mg}$ of bST (Posilac; Monsanto, St. Louis, MO) at the beginning of the study and at 14-d intervals thereafter.

The experiment was conducted as a split-plot study. Cows were randomly assigned to a diet with either 11 or $9 \%$ RDP (DM basis) as whole plot. In formulating the diets with NRC (2001), the desired RDP level was achieved by altering the proportion of soybean meal with soybean meal, SoyPlus (West Central Soy, Ralston, IA), and blood meal (Table 1). Subplot treatments were (DM basis) $10 \%$ refined starch and $0 \%$ dextrose (ST), $5 \%$ refined starch and $5 \%$ dextrose (DX-ST), and $0 \%$ refined starch and 10\% dextrose (DX). Both refined starch (Cargill, Minneapolis, MN) and dextrose (Archer Daniels Midland, Decatur, IL) were food-grade products derived from corn starch. The 9 cows in each RDP level were randomly allocated into three $3 \times 3$ Latin squares with periods of $28 \mathrm{~d}$ ( $14 \mathrm{~d}$ of adaptation and 14 $\mathrm{d}$ of sampling). Despite the confounding between RDP level and square, this design was chosen because of the desired greater precision in comparing the effects of carbohydrate source than RDP level and because of recent suggestions that some N-related responses require more than 3 wk of adaptation for stabilization (Zanton, 2016; Barros et al., 2017). Thus, effects of RDP level in this study were assessed in a completely randomized design that lasted $84 \mathrm{~d}$, allowing for the determination of the interaction between RDP level and period. The week before initiation of the study, cows in each RDP level had similar characteristics, as average $( \pm \mathrm{SD})$ milk production was $43.1 \pm 3.4$ and $41.3 \pm 3.5 \mathrm{~kg} / \mathrm{d}$, BW was $644 \pm 37$ and $635 \pm 53 \mathrm{~kg}$, and DIM was $147 \pm$ 10 and $149 \pm 10$ for cows fed 11 and 9\% RDP diets, respectively. Diets contained the same concentrations of forage, $\mathrm{CP}, \mathrm{NDF}, \mathrm{ADF}$, ash, and ether extract and similar concentrations of $\mathrm{NFC}$ and $\mathrm{NE}_{\mathrm{L}}$ but decreasing levels of starch (from $28 \%$ to $19 \%$ ) and increasing levels of water-soluble carbohydrates (from $4.6 \%$ to $13.8 \%$ ) as refined starch was replaced with dextrose in the diets (DM basis; Table 1). Calculated nutritional entities, including RDP levels of 11.4 and $9.2 \%$, reported in Table 1 were based on actual BW, DMI, milk production, and feed composition measured during the study.

For each diet, a customized mix was prepared with concentrates, macrominerals, a micromineral and vitamin premix, and Smartamine (Adisseo USA Inc., Alpharetta, GA). All diets were mixed daily and offered as a TMR. Due to the availability of forages, different cuts of alfalfa silage were used for each period and corn silage was changed at the beginning of the third period. The alfalfa silage contained $20.2,25.5$, and $16.9 \% \mathrm{CP}$ and $40.9,34.6$, and $40.4 \%$ NDF (DM basis) in periods 1 , 
2 , and 3, respectively. At the beginning of each period, diets were reformulated to account for differences in chemical composition (DM, CP, and NDF) among cuts.

\section{Sampling, Analysis, and Calculations}

DMI and Milk Production. Cows were fed once daily $(0730 \mathrm{~h})$ with TMR delivery $10 \%$ above refusals. However, during wk 3 and 4 of each period, feeding time was staggered $(0730$ and $0900 \mathrm{~h}$ for the 9 and $11 \%$ RDP diets, respectively) to make it possible to measure enteric $\mathrm{CH}_{4}$ at fixed times relative to feeding for all cows. Forages were sampled for moisture content weekly, and proportion of forages and customized mix was adjusted accordingly. All feed ingredients and TMR were sampled weekly, and refusal samples from each cow were collected daily in wk 3 and 4 of each period. All feed samples were stored at $-20^{\circ} \mathrm{C}$ until dried

Table 1. Ingredients and chemical composition of dietary treatments ${ }^{1,2}$

\begin{tabular}{|c|c|c|c|c|c|c|}
\hline Item & \multicolumn{3}{|c|}{$11 \% \mathrm{RDP}$ in ration $\mathrm{DM}$} & \multicolumn{3}{|c|}{$9 \% \mathrm{RDP}$ in ration $\mathrm{DM}$} \\
\hline \multicolumn{7}{|l|}{ Ingredient ( $\%$ of DM) } \\
\hline Alfalfa silage & 27.8 & 27.8 & 27.8 & 27.8 & 27.8 & 27.8 \\
\hline Wheat straw & 6.9 & 6.9 & 6.9 & 6.9 & 6.9 & 6.9 \\
\hline Refined starch $^{3}$ & 10.0 & 5.0 & 0.0 & 10.0 & 5.0 & 0.0 \\
\hline Soybean meal & 13.7 & 13.7 & 13.7 & 1.9 & 1.9 & 1.9 \\
\hline SoyPlus ${ }^{5}$ & 1.7 & 1.7 & 1.7 & 12.5 & 12.5 & 12.5 \\
\hline Blood meal & 0.0 & 0.0 & 0.0 & 1.0 & 1.0 & 1.0 \\
\hline Other ingredients ${ }^{6}$ & 1.6 & 1.6 & 1.6 & 1.6 & 1.6 & 1.6 \\
\hline \multicolumn{7}{|c|}{ Laboratory measurements $^{7}$ ( $\%$ of DM unless indicated) } \\
\hline Diet DM (\% as fed) & 56.5 & 56.5 & 56.6 & 56.4 & 56.5 & 56.5 \\
\hline $\mathrm{CP}$ & 16.4 & 16.4 & 16.4 & 16.5 & 16.5 & 16.5 \\
\hline Water-soluble carbohydrate & 4.8 & 9.4 & 14.0 & 4.4 & 9.0 & 13.6 \\
\hline \multicolumn{7}{|c|}{ Calculated composition $^{9}$ (\% of DM unless indicated) } \\
\hline Forage NDF & 26.3 & 26.3 & 26.3 & 26.3 & 26.3 & 26.3 \\
\hline $\mathrm{NFC}^{10}$ & 46.2 & 46.2 & 46.2 & 45.2 & 45.2 & 45.3 \\
\hline RDP & 11.4 & 11.4 & 11.5 & 9.3 & 9.2 & 9.2 \\
\hline RUP & 5.0 & 5.1 & 5.0 & 7.1 & 7.1 & 7.1 \\
\hline MP supplied (g/d) & 2,228 & 2,322 & 2,258 & 2,563 & 2,838 & 2,826 \\
\hline MP balance $(\mathrm{g} / \mathrm{d})$ & -239 & -138 & -210 & 28 & 189 & 227 \\
\hline $\mathrm{NE}_{\mathrm{L}}^{11}(\mathrm{Mcal} / \mathrm{kg}$ of $\mathrm{DM})$ & 1.56 & 1.54 & 1.57 & 1.55 & 1.55 & 1.58 \\
\hline
\end{tabular}

${ }^{1}$ Diet composition was presented as average of the 3 periods. Adjustment of proportion of alfalfa silage, corn silage, and wheat straw within forage was made between periods to make diet chemical composition close between periods. Composition of the diets was reconstituted from analysis of individual feed components. Inclusion (\% of diet DM) for corn silage, alfalfa silage, and wheat straw was 25,30 , and $6 \%$ for period $1 ; 31.5,21.0$, and $8.5 \%$ for period 2 ; and $22.5,32.4$, and $6.1 \%$ for period 3 , respectively.

${ }^{2} \mathrm{ST}=10 \%$ refined starch and $0 \%$ dextrose; DX-ST $=5 \%$ refined starch and $5 \%$ dextrose; DX $=0 \%$ refined starch and $10 \%$ dextrose. 11 and $9 \%$ RDP in diet, all on a diet DM basis.

${ }^{3}$ Cargill, Minneapolis, MN.

${ }^{4}$ Archer Daniels Midland, Decatur, IL.

${ }^{5}$ West Central Cooperative, Ralston, IA.

${ }^{6}$ Other ingredients included $0.10 \%$ Smartamine (Adisseo USA Inc., Alpharetta, GA.), $0.80 \%$ sodium bicarbonate, $0.40 \%$ calcium carbonate, and $0.30 \%$ vitamin and mineral premix (which included $51.2 \%$ chloride, $0.5 \%$ calcium, $34 \%$ sodium, $0.09 \%$ sulfur, $78.2 \mathrm{mg} / \mathrm{kg}$ of cobalt, $4,870 \mathrm{mg} /$ $\mathrm{kg}$ of copper, $469 \mathrm{mg} / \mathrm{kg}$ of iodine, $14,400 \mathrm{mg} / \mathrm{kg}$ of manganese, $89.5 \%$ selenium, 20,700 mg/kg of zinc, 93,400 IU of vitamin A, 187,000 IU of vitamin $\mathrm{D}$, and 3,960 IU of vitamin E), all on a DM basis of TMR.

${ }^{7}$ Diet CP, aNDFom, ADF, starch, water-soluble carbohydrate, ether extract, and ash were from feed analyzed by Dairyland Laboratory, Arcadia, WI.

${ }^{8} \mathrm{NDF}$ reported as ash corrected.

${ }^{9}$ Forage NDF, NFC, RDP, RUP, MP supplied and balance, and $\mathrm{NE}_{\mathrm{L}}$ were based on chemical composition of feedstuffs and calculated by NRC (2001) based on actual DMI, milk production, milk composition, and BW.

${ }^{10} \mathrm{NFC}=100-\mathrm{CP}-\mathrm{NDF}-$ ether extract - ash.

${ }^{11}$ Estimated using NRC (2001) with actual performance data. 
for further analysis. Milk yield was recorded daily from morning $(0430 \mathrm{~h})$ and afternoon $(1630 \mathrm{~h})$ milkings, and milk samples were collected for 4 consecutive milkings from d 18 to 20 and from d 25 to 27 of each period. All milk samples were analyzed for fat, true protein, lactose, and MUN concentrations by infrared analysis (Agsource Milk Analysis Laboratory, Menomonie, WI) with a Foss FT6000 (Foss Electric, Hillerød, Denmark). Production of fat- and protein-corrected milk (FPCM) was computed according to IDF (2015). Average BW of each cow in each period was obtained from measurements conducted at $0630 \mathrm{~h}$ on $\mathrm{d} 18,19,25$, and 26. Feed efficiency was calculated as FPCM divided by DMI, and $\mathrm{N}$ use efficiency (i.e., efficiency of conversion of intake $\mathrm{N}$ into milk protein) was calculated as milk protein $\mathrm{N}$ divided by total $\mathrm{N}$ intake, or ( $\mathrm{kg}$ of milk true protein/6.38)/(kg of DMI $\times$ dietary CP \%/6.25).

$\mathrm{CH}_{4}$ Production. The GreenFeed unit was zeroed and span-calibrated before the start of each sampling period with pure $\mathrm{N}$ gas, $\mathrm{CH}_{4}$, and $\mathrm{CO}_{2}$ (474 and 4,497 ppm, respectively). Over $4 \mathrm{~d}$ (d 18-21) of wk 3 of each period, enteric $\mathrm{CH}_{4}$ production was measured on each cow at 11 time points. Approximately $8 \mathrm{~min}$ was required per cow (5 min of measurement with no more than $100 \mathrm{~g}$ of concentrate mix delivery, 2 min for background $\mathrm{CH}_{4}$ concentration, and 1 min to move the equipment). The staggering of feeding times $1.5 \mathrm{~h}$ apart for the 9 cows fed the $9 \%$ RDP diet and the 9 cows fed the $11 \% \mathrm{RDP}$ diet allowed us to measure enteric $\mathrm{CH}_{4}$ at fixed time relative to feeding as desired. For example, $\mathrm{CH}_{4}$ data collection started on d 18 at $0830 \mathrm{~h}(1 \mathrm{~h}$ after feeding) for cows fed the $9 \%$ RDP diet followed by measurements starting at $1000 \mathrm{~h}$ for cows fed the $11 \% \mathrm{RDP}$ diet (also $1 \mathrm{~h}$ after feeding). Thus, $\mathrm{CH}_{4}$ was measured in a preset order of dietary RDP level, but the order of the 3 cows fed the same diet therein was selected randomly. This protocol allowed for all measurements to be conducted within 21 min of target time. This protocol was repeated later in the day and across the next $3 \mathrm{~d}$ to gather production data $1,2.5,4,5.5,10,11.5$, $13,14.5,16,17.5$, and $22.5 \mathrm{~h}$ after feeding. Enteric $\mathrm{CH}_{4}$ production $(\mathrm{g} / \mathrm{d})$ was calculated as the average of the 11 daily estimates derived from each sampling. Hourly emission rate at each sampling time was calculated as the corresponding daily $\mathrm{CH}_{4}$ production divided by 24 .

Feed Composition and Indigestible NDF. Feed samples were dried at $60^{\circ} \mathrm{C}$ in a forced-draft oven for 48 $\mathrm{h}$, and dried samples were then ground to pass a 1-mm Wiley mill screen (Arthur H. Thomas, Philadelphia, PA). Each feed ingredient (alfalfa silage, corn silage, wheat straw, and concentrate mixes) was composited for the last 2 wk of each period. Samples were analyzed by Dairyland Laboratories (Arcadia, WI) for total N (method 990.03; AOAC International, 2016), amylase- treated NDF (method 2002.04; AOAC International, 2016), ADF and lignin (method 973.18; AOAC International, 2016), ether extract (method 920.39; AOAC International, 2016), and ash and OM (method 942.05; AOAC International, 2016). In addition, starch and water-soluble carbohydrate contents of feed samples were analyzed according to Vidal et al. (2009) and Deriaz (1961), respectively. In situ ruminal incubation was done for each feed ingredient, refusals, and fecal samples using 2 ruminally cannulated cows to determine indigestible NDF (iNDF; Huhtanen et al., 1994). Duplicate bags were inserted into a nylon laundry mesh bag $(38.1 \mathrm{~cm} \times 45.7 \mathrm{~cm}$; Home Products International, Chicago, IL), which was inserted into the rumen via the cannula. After $288 \mathrm{~h}$ of incubation, the mesh bags were removed from the rumen, submerged in cold water, and rinsed to remove particles on the surface of bags. Bags were then rinsed in a washing machine with cold water for two 12-min rinse cycles. After drying at $60^{\circ} \mathrm{C}$ in a forced-air oven, the bags were washed with an Ankom200 Fiber Analyzer with $\alpha$-amylase (Ankom Technology, Fairport, NY) and sodium sulfide to determine iNDF.

Serum Urea-N. Blood samples $(\sim 10 \mathrm{~mL})$ were collected from each cow by coccygeal venipuncture with vacutainer tubes at $4 \mathrm{~h}$ after feeding on d 26 of each period. Samples were centrifuged immediately at 3,200 $\times g$ at $4^{\circ} \mathrm{C}$ for $10 \mathrm{~min}$, and the serum fraction was analyzed for urea- $\mathrm{N}$ concentration (serum urea-N) with a 96-well plate reader (Synergy H1 Multi-Mode Reader; BioTek, Winooski, VT).

Ruminal Measurements. Ruminal fluid of each cow was collected by rumenocentesis (Nordlund and Garrett, 1994) approximately $4 \mathrm{~h}$ after feeding on d 27 and 28 of each period for cows fed the 9 and $11 \%$ RDP diets, respectively. Approximately $10 \mathrm{~mL}$ of ruminal fluid was collected from the ventral sac area and tested instantly for $\mathrm{pH}$ (Laqua Twin $\mathrm{pH}$ meter, model B-713; Spectrum Technologies Inc., Plainfield, IL). Four 1-mL aliquots were pipetted into 4 microfuge tubes and stored at $-20^{\circ} \mathrm{C}$ until further analysis, with 2 tubes containing $20 \mu \mathrm{L}$ of $50 \%$ trichloroacetic acid and 2 tubes containing $20 \mu \mathrm{L}$ of $\mathrm{H}_{2} \mathrm{SO}_{4}$ for analysis of ammonia- $\mathrm{N}\left(\mathrm{NH}_{3}-\mathrm{N}\right)$ and VFA concentrations, respectively. For determination of the concentration of VFA and $\mathrm{NH}_{3}-\mathrm{N}$, the samples were thawed to room temperature and centrifuged at 10,000 $\times g$ at $4^{\circ} \mathrm{C}$ for $3 \mathrm{~min}$. The supernatant was transferred to $\mathrm{GC}$ vials for analysis of VFA concentration using GC (Clarus 500 Gas Chromatograph; PerkinElmer Inc., Shelton, CT). Ammonia-N concentration of the ruminal fluid was analyzed by a procedure modified from Chaney and Marbach (1962).

Urine. Spot urine samples were collected from each cow during wk 4 of each period at 6 time points with 
4-h intervals to cover the 24-h clock over $3 \mathrm{~d}$ (1130 and $1930 \mathrm{~h}$ on $\mathrm{d} 25$; 0330,1530 , and $2330 \mathrm{~h}$ on $\mathrm{d} 26$; and $0730 \mathrm{~h}$ on $\mathrm{d} 27$ to get samples representing $4,8,12$, 16,20 , and $24 \mathrm{~h}$ after feeding). The urine was obtained through stimulation of the vulva. Urine samples were acidified with $0.072 \mathrm{M} \mathrm{H}_{2} \mathrm{SO}_{4}$ with a $4: 1$ volumetric ratio of acid to urine. Samples were then frozen at $-20^{\circ} \mathrm{C}$ for later analysis. After thawing at room temperature, urine samples were composited for each cow by period and analyzed for total N (Leco FP-2000 N Analyzer, Leco Instruments Inc., St. Joseph, MI). In addition, urinary urea- $\mathrm{N}$ concentration and creatinine concentration were analyzed with a colorimetric assay and a picric acid assay (Oser, 1965) adapted to flow-injection analysis, respectively, both using Lachat Quik-Chem 8000 FIA (Lachat Instruments, Milwaukee, WI). Using wk 4 BW, total daily urine volume was estimated assuming a constant creatinine excretion rate of $29 \mathrm{mg} /$ $\mathrm{kg}$ of BW (Valadares et al., 1999). Concentrations of allantoin and uric acid in urine samples were determined by a colorimetric method (Chen and Gomes, 1992) and Infinity uric acid liquid stable reagent (Thermo Fisher Scientific Inc., Middletown, VA), respectively, both with a 96-well plate reader (Synergy H1 Multi-Mode Reader; BioTek, Winooski, VT). Urinary allantoin and uric acid excretions were calculated from the respective concentrations multiplied by estimated total daily urine volume. Urinary purine derivatives (PD) were calculated as the sum of daily allantoin and uric acid excreted in the urine.

Feces. Spot fecal samples were collected from each cow immediately after applying the urine collection procedure. At each sampling, approximately $100 \mathrm{~g}$ of fresh feces was collected from the rectum, and the feces from the 6 spot samplings were composited for each cow. Samples were then frozen at $-20^{\circ} \mathrm{C}$ for later analysis. Upon thawing, composite fecal samples of each cow were dried at $60^{\circ} \mathrm{C}$ in a forced-draft oven for $96 \mathrm{~h}$, ground through a 1-mm Wiley mill screen (Arthur H. Thomas Co.), and analyzed for NDF and iNDF (with Ankom described above), starch (Vidal et al., 2009), and total N (Leco FP-2000 N Analyzer). In addition to iNDF content, feces were analyzed for total ash by igniting the dry ground fecal sample in a furnace at $600^{\circ} \mathrm{C}$ for $2 \mathrm{~h}$ (the same method used to determine ash in feed samples).

Nutrient Intake, Apparent Digestibility, and $N$ Balance Calculations. In this study, iNDF served as an internal marker for estimation of fecal DM output and nutrient digestibility. The amount of nutrient intake (OM, NDF, $\mathrm{CP}$, and starch) and iNDF intake during wk 4 of each period were calculated for each cow from nutrient concentration in feed ingredient multiplied by DMI minus respective refusal amounts.
Feces output (DM basis) was estimated as iNDF intake divided by iNDF concentration in feces (Cochran et al., 1986). Total-tract apparent digestibility of nutrients was determined from amount of nutrient in fecal excretion and daily nutrient intake. Nitrogen retained was calculated as $\mathrm{N}$ intake - (milk true protein $\mathrm{N}+$ fecal $\mathrm{N}+$ urinary $\mathrm{N})$.

\section{Statistical Analysis}

Data were analyzed using PROC MIXED of SAS (version 9.4; SAS Institute Inc., Cary, NC). Before analysis, measurements repeated over time (DMI, milk production, milk component yields, and $\mathrm{CH}_{4}$ production) and all other measurements were reduced to period means for each cow. Variables were analyzed using the following model:

$$
\begin{aligned}
Y_{i j k l}=\mu & +R_{i}+S_{q: i}+N_{j}+P_{k}+N_{i j} \\
& +R_{i k}+C_{l: q}+e_{i j k l},
\end{aligned}
$$

where $Y_{\mathrm{ijkl}}$ is the response variable $(\mathrm{n}=54) ; \mu$ is the overall mean; $\mathrm{R}_{\mathrm{i}}$ is the fixed effect of RDP level in the $\operatorname{diet}(11$ vs. $9 \%) ; \mathrm{S}_{\mathrm{q}: \mathrm{i}}$ is the random effect of square within RDP level i; $\mathrm{N}_{\mathrm{j}}$ is the fixed effect of NFC source in the diet (ST vs. DX-ST vs. DX); $\mathrm{P}_{\mathrm{k}}$ is the fixed effect of period; $\mathrm{NR}_{\mathrm{ij}}$ is the effect of interaction between $\mathrm{NFC}$ source and RDP level; $\mathrm{RP}_{\mathrm{ik}}$ is the interaction between $\mathrm{RDP}$ level and period; $\mathrm{C}_{\text {l:q }}$ is the random effect of cow within square and RDP; and $\mathrm{e}_{\mathrm{ijkl}}$ is the random residual error. The above model was set a priori, and the reason it included the interaction between RDP level and period was explained earlier.

For hourly $\mathrm{CH}_{4}$ emission rate analysis, the intended data $(\mathrm{n}=594)$ included the measurements collected from each cow $(\mathrm{n}=18)$ at each time point $(\mathrm{n}=11)$ in each period $(\mathrm{n}=3)$. There were 75 missing data points because $\mathrm{CH}_{4}$ was not captured at the specified time (n $=59$, or $9.9 \%$ of intended data) or because a value was considered an outlier when the estimated $\mathrm{CH}_{4}$ emission rate was greater than $33.3 \mathrm{~g} / \mathrm{h}$ (corresponding to $>800$ $\mathrm{g} / \mathrm{d}$; Dorich et al., 2015; $\mathrm{n}=16$, or $1.7 \%$ of intended data). The model used was

$$
\begin{aligned}
& \mathrm{Y}_{\mathrm{ijklm}}=\mu+\mathrm{R}_{\mathrm{i}}+\mathrm{S}_{\mathrm{q}: \mathrm{i}}+\mathrm{N}_{\mathrm{j}}+\mathrm{P}_{\mathrm{k}}+\mathrm{NR}_{\mathrm{ij}}+\mathrm{RP}_{\mathrm{ik}} \\
& +\mathrm{RNP}_{\mathrm{ijk}}+\mathrm{T}_{\mathrm{m}}+\mathrm{TR}_{\mathrm{mi}}+\mathrm{TN}_{\mathrm{mj}}+\mathrm{C}_{\mathrm{l:q}}+\mathrm{e}_{\mathrm{ijklm}},
\end{aligned}
$$

where $Y_{\mathrm{ijk} k m}$ is the response variable; $\mu, \mathrm{R}_{\mathrm{i}}, \mathrm{S}_{\mathrm{q}: \mathrm{i}}, \mathrm{N}_{\mathrm{j}}, \mathrm{P}_{\mathrm{k}}$, $\mathrm{NR}_{\mathrm{ij}}, \mathrm{RP}_{\mathrm{ik}}$, and $\mathrm{C}_{\mathrm{l:q}}$ are as described previously; $\mathrm{RNP}_{\mathrm{ijk}}$ is the random effect of 3-way interaction of period, NFC source, and RDP level; $\mathrm{T}_{\mathrm{m}}$ is the fixed effect of time (h after feeding); $\mathrm{TR}_{\mathrm{mi}}$ is the interaction between time and 
$\mathrm{RDP}$ level; $\mathrm{TN}_{\mathrm{mj}}$ is the interaction between time and NFC source; and $\mathrm{e}_{\mathrm{ijk} k \mathrm{~m}}$ is the random residual error. Because not all time intervals between $\mathrm{CH}_{4}$ measurements were constant, spatial power covariance structure was used for the analysis of time as a repeated measure. Reported hourly emission rate was least squares means separated by Tukey's test.

Effects of replacing refined starch with dextrose in diet were tested using preplanned polynomial orthogonal contrasts for linear and quadratic responses. All reported values were least squares means. Linear effects of molar percentages of ruminal VFA on daily $\mathrm{CH}_{4}$ production were investigated with a mixed model with period and cow as random effects. For all procedures, significance was declared at $P \leq 0.05$ and tendency at $0.05<P \leq 0.10$.

\section{RESULTS AND DISCUSSION}

\section{DMI and Lactation Performance}

There was no significant carbohydrate source $\times$ RDP level interaction for any of the cow performance response variables presented in Table 2 , but milk true protein yield tended to be influenced by the interaction between RDP level and period $(P=0.08)$. The differential pattern of change over the 3 sampling periods covering the $84 \mathrm{~d}$ of the study provided additional support to the contention of long-term adaptation of $\mathrm{N}$ metabolism to changing level or composition of dietary CP (Zanton, 2016; Barros et al., 2017). In this study, the inclusion of dextrose in the diet had both positive linear $(P<0.01)$ and quadratic $(P=0.01)$ effects on DMI. Greater DMI has been observed when starch in the diet was replaced with disaccharide (Gao and Oba, 2016) or dried molasses (Broderick and Radloff, 2004). Furthermore, the changes in DMI observed in our study were consistent with cows' preference for sweet taste (Nombekela et al., 1994) and the hepatic oxidation theory of intake regulation suggesting stronger satiety signals with increasing starch consumption (Allen et al., 2009). Indeed, using our digestibility data, we found evidence of a negative correlation between DMI and starch intake $(\mathrm{r}=-0.72 ; P=0.10)$. Carbohydrate source did not affect milk, FPCM, protein and lactose concentrations, and yield of major milk components, but replacing refined starch with dextrose tended to increase milk fat concentration in both linear $(P=0.06)$ and quadratic $(P=0.09)$ fashion and decreased feed efficiency (Table 2). The milk fat percentages in this trial were relatively high, but similar values have been reported in Broderick and Radloff (2004) for diets with similar starch level in diets. Furthermore, similar to our results, that study showed a tendency for a quadratic effect on milk fat percentage when starch was replaced with sugar (in the form of molasses). Furthermore, carbohydrate source affected milk MUN in a quadratic fashion, with greater values observed for the DX-ST diet than the ST or DX diets (Table 2). Similar to our results, Krause et al. (2003) did not find any effects of refined corn starch (up to $18 \%$ of dietary DM), nor did Broderick and Radloff (2004) find any effect of dried molasses (up to $12 \%$ of dietary DM) on milk production. In contrast to our results, however, Broderick et al. (2008) reported greater milk fat yield in cows fed a high-starch diet compared with a high-sucrose diet.

In this study, dietary RDP level did not affect DMI, which agreed with Reynal and Broderick (2005) and Kalscheur et al. (2006). Although cows fed 9\% RDP diets had numerically greater milk (37.4 vs. $34.8 \mathrm{~kg} / \mathrm{d}$ ), FPCM (37.7 vs. $35.0 \mathrm{~kg} / \mathrm{d}$ ), milk fat (1.57 vs. 1.44 $\mathrm{kg} / \mathrm{d}$ ), and lactose (1.80 vs. $1.63 \mathrm{~kg} / \mathrm{d}$ ) yields than cows fed $11 \%$ RDP diets, these differences did not reach significance because of the limited number of observations and, by design, the limited power to detect differences in the main plot. The literature reported inconsistent effects of RDP level on lactation performances. Reynal and Broderick (2005) did not find a difference in milk yield with 4 RDP levels ranging from 10.6 to $13.2 \%$ in diets with increasing CP content from 17.2 to $18.8 \%$ (DM basis). However, Kalscheur et al. (2006) reported linear increases in milk production, protein, and fat yields when cows were fed diets with RDP levels of $6.8,8.2,9.6$, and $11.0 \%$ when RUP was kept constant at $5.8 \%$ of dietary DM. Zanton et al. (2013) reported a tendency of greater milk production from cows fed corn silage-based diets with approximately $17.5 \% \mathrm{CP}$ and 9.6\% RDP compared with $10.5 \%$ RDP. In our study, the decrease in RDP was accompanied by an increase in RUP, in part by substituting a heat-treated soy product for soybean meal. In other studies, such replacement resulted in increased milk production (Santos et al., 1998; Hall, 2013).

\section{Ruminal Metabolites}

There was no carbohydrate source $\times$ RDP level interaction for any of the ruminal response variables (all $P>0.32$ ) presented in Table 3. However, ruminal $\mathrm{pH}$ tended to decrease linearly $(P=0.08)$ when replacing refined starch with dextrose in the diet (Table 3). Mills et al. (2001) suggested that sugars tend to ferment faster and degrade more completely than starch in the rumen, thus resulting in a lower ruminal $\mathrm{pH}$. In contrast, Oba (2011) suggested that the rapid disappearance of sugar does not necessarily result in lower ruminal $\mathrm{pH}$ because the sugar may be used for microbial glycogen synthesis, which in effect slows down the rate of ruminal acid 
Table 2. Effect of dietary treatments on cow performance ${ }^{1}$

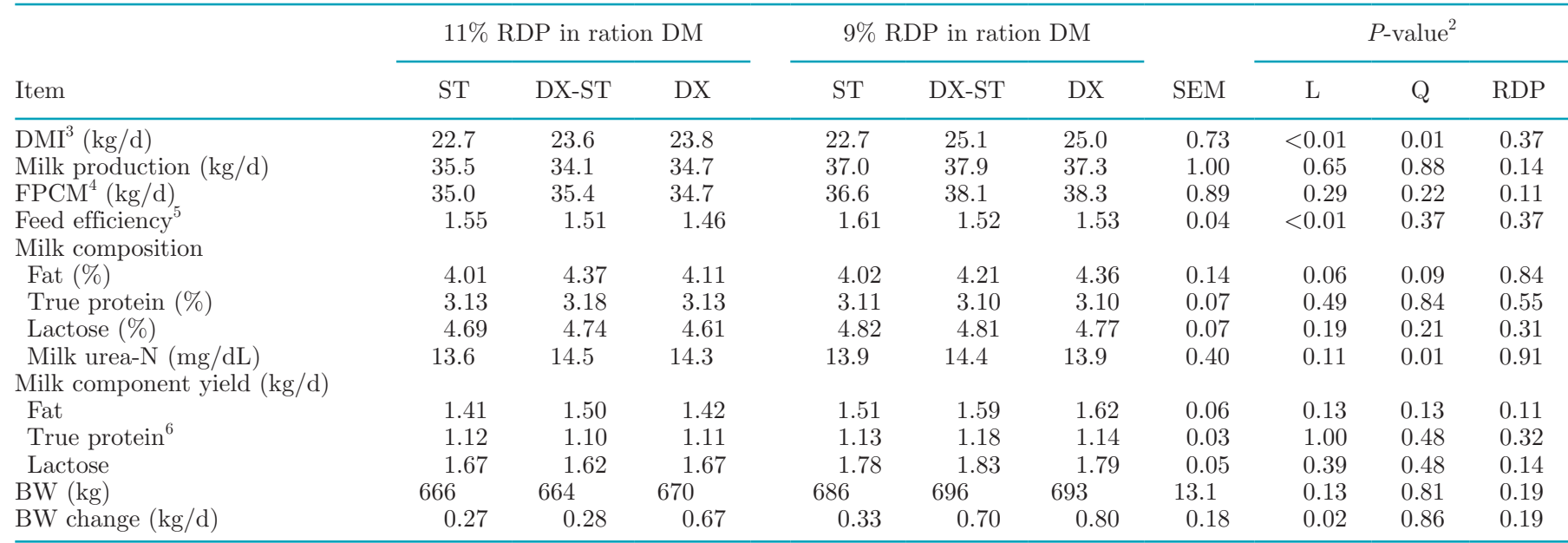

${ }^{1} \mathrm{ST}=10 \%$ refined starch and $0 \%$ dextrose; DX-ST $=5 \%$ refined starch and $5 \%$ dextrose; DX $=0 \%$ refined starch and $10 \%$ dextrose in ration DM.

${ }^{2}$ Main effect of carbohydrate source (ST, DX-ST, or DX) partitioned into linear (L) and quadratic (Q) components and main effect of RDP level. Unless noted in separate footnotes, the interaction between NFC source and RDP level was not significant $(P>0.10)$.

${ }^{3}$ Measured in wk 3 and 4 of each period; carbohydrate source $\times$ RDP level interaction $(P=0.09)$.

${ }^{4}$ Fat- and protein-corrected milk measured in wk 3 and 4 of each period; FPCM $=$ milk production $(\mathrm{kg} / \mathrm{d}) \times(0.1226 \times$ fat $\%+0.0776 \times$ true protein $\%+0.2534)(\mathrm{IDF}, 2015)$.

${ }^{5}$ Feed efficiency $=$ FPCM/DMI.

${ }^{6} \mathrm{RDP}$ level $\times$ period interaction $(P=0.08)$; true protein yield $(\mathrm{kg} / \mathrm{d})$ was $1.21,1.10$, and 1.02 for $11 \%$ RDP level but $1.23,1.19$, and 1.03 for $9 \%$ RDP level in periods 1,2 , and 3 , respectively.

production. In our study, replacing refined starch with dextrose in the diet linearly increased the molar percentages of butyrate and valerate but decreased individual (isobutyrate, 2-methylbutyrate, and isovalerate) and total branched-chain VFA. These results agreed with in situ (Hall et al., 2010; Gao and Oba, 2016) and in vitro (Vallimont et al., 2004) studies that found greater molar percentage of butyrate when fermenting simple sugars (sucrose, lactose) compared with starch. Similar to our results, Khezri et al. (2009) reported an increase in molar percentage of butyrate and a decrease in branched-chain VFA when replacing corn starch with sucrose in the diet. As branched-chain VFA originate from the deamination and decarboxylation of branchedchain AA (Allison, 1970), the decrease in branchedchain VFA observed here may be explained in part by the results of Broderick et al. (2008), who reported a linear reduction in total ruminal AA when replacing starch with sucrose in the diet. The absence of an effect of carbohydrate source on the molar percentage of propionate observed here agreed with results reported by Hall et al. (2010) and Vallimont et al. (2004) when partially replacing sugar with starch in diets.

Dietary RDP concentration influenced ruminal fluid $\mathrm{NH}_{3}-\mathrm{N}$ concentration, which averaged 12.3 and $7.2 \mathrm{mg} /$ $\mathrm{dL}$ for cows fed 11 and $9 \%$ RDP diets, respectively $(P$ $<0.01)$. Reducing RDP is an effective way to reduce ruminal $\mathrm{NH}_{3}-\mathrm{N}$ concentration (Reynal and Broderick, 2005; Zanton et al., 2013). In the present study, $\mathrm{NH}_{3}-$ $\mathrm{N}$ concentrations for all $11 \% \mathrm{RDP}$ diets were greater than $11.8 \mathrm{mg} / \mathrm{dL}$, which Reynal and Broderick (2005) indicated was the minimal concentration for maximal microbial protein production. However, the reduced ruminal $\mathrm{NH}_{3}-\mathrm{N}$ concentrations for cows fed $9 \% \mathrm{RDP}$ diets may have limited microbial protein synthesis (a contention supported by the daily excretion of purine derivatives discussed below).

\section{Enteric $\mathrm{CH}_{4}$ Production}

Dietary Treatment Effects. There was no carbohydrate source $\times$ RDP level interaction for any of the enteric $\mathrm{CH}_{4}$ measures (all $P>0.43$ ), but daily enteric $\mathrm{CH}_{4}$ production of cows fed the ST diet was 7.1 and $6.8 \%$ lower compared with the DX-ST and DX diets (451, 486, and $484 \mathrm{~g}$ of $\mathrm{CH}_{4} / \mathrm{d}$ for ST, DX-ST, and DX diets, respectively; Table 4). The greater $\mathrm{CH}_{4}$ production observed for cows fed the DX and DX-ST diets was likely due to the effect of greater DMI (Table 2) compared with cows fed the ST diets. Dry matter intake has been identified as the main driver of daily enteric $\mathrm{CH}_{4}$ production (Yan et al., 2000; Ramin and Huhtanen, 2013). In our study, cows fed the DX and DX-ST diets had similar molar percentage of ruminal 
Table 3. Effect of dietary treatments on ruminal metabolism and serum urea-nitrogen $(\mathrm{N})^{1}$

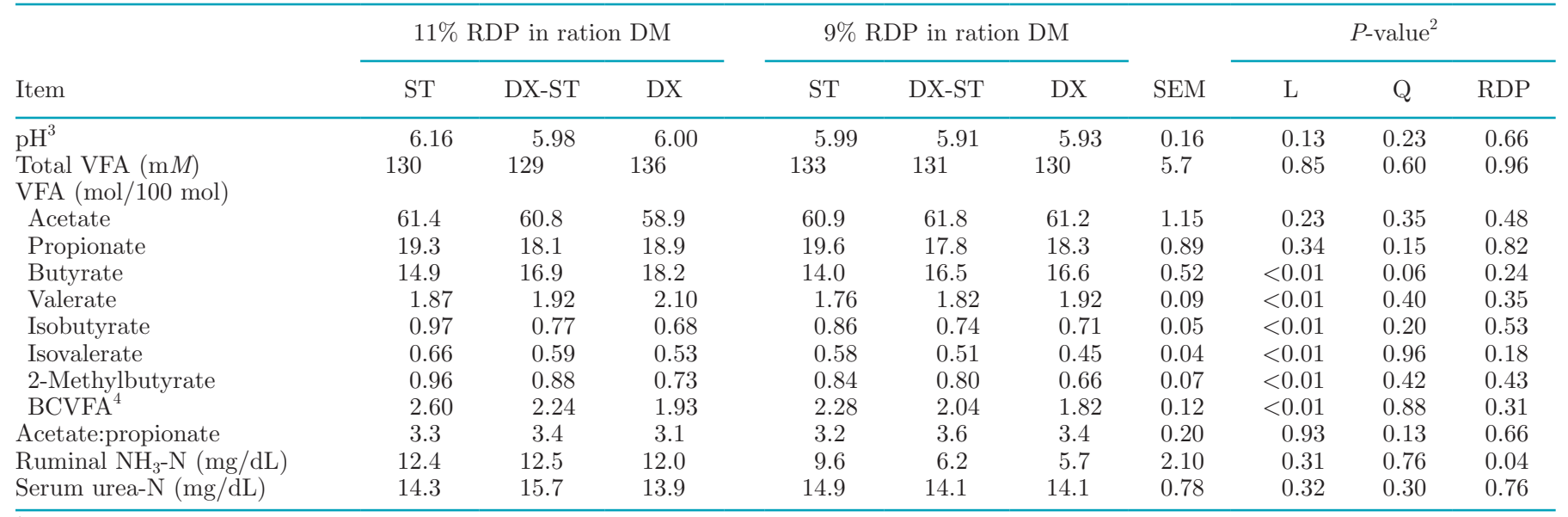

${ }^{1} \mathrm{ST}=10 \%$ refined starch and $0 \%$ dextrose; DX-ST $=5 \%$ refined starch and $5 \%$ dextrose; DX $=0 \%$ refined starch and $10 \%$ dextrose in ration DM.

${ }^{2}$ Main effect of carbohydrate source (ST, DX-ST, or DX) partitioned into linear (L) and quadratic (Q) components and main effect of RDP level. Unless noted in separate footnotes, the interaction between carbohydrate source and RDP level was not significant $(P>0.10)$.

${ }^{3}$ These data were generated from ruminal fluid collected $4 \mathrm{~h}$ after feeding during wk 4 .

${ }^{4}$ Branched-chain VFA $=$ isobutyrate +2 -methylbutyrate + isovalerate.

propionate but greater molar percentage of ruminal butyrate than cows fed the ST diets (Table 3). The fermentation of carbohydrate into acetate and butyrate yields $\mathrm{H}_{2}$, a substrate for $\mathrm{CH}_{4}$ synthesis (Moss et al., 2000). Thus, our results agreed with earlier empirical evidence (Hindrichsen et al., 2005) and modeling efforts (Bannink et al., 2008; Dijkstra et al., 2011) suggesting greater enteric $\mathrm{CH}_{4}$ production from fermentation of sugars compared with starch. Data in Table 5 indicated that $\mathrm{CH}_{4}$ production was negatively related to the molar percentage of ruminal propionate and positively related to the molar percentage of ruminal butyrate. Measured as molar percentages, the components of VFA mixture are intrinsically codependent. A recent modeling effort of ruminal VFA measured in cattle suggested that the acetate $\times$ butyrate:propionate ratio best explained the contribution of VFA to variation in $\mathrm{CH}_{4}$ yield $(\mathrm{g} /$ kg of DMI; Palarea-Albaladejo et al., 2017). However, in our study, dietary treatments did not affect enteric $\mathrm{CH}_{4}$ yield $(20 \mathrm{~g} / \mathrm{kg}$ of DMI $)$ and intensity $(13.1 \mathrm{~g} / \mathrm{kg}$ of FPCM) or $\mathrm{CH}_{4}$ emission expressed per kilogram of OM intake (21.6 g), NDF intake (70.4 g), OM digested (30.1 $\mathrm{g})$, and NDF digested (169.5 g). Similar findings were also reported by Hatew et al. (2015).

Table 4. Effects of dietary treatments on methane $\left(\mathrm{CH}_{4}\right)$ emission ${ }^{1}$

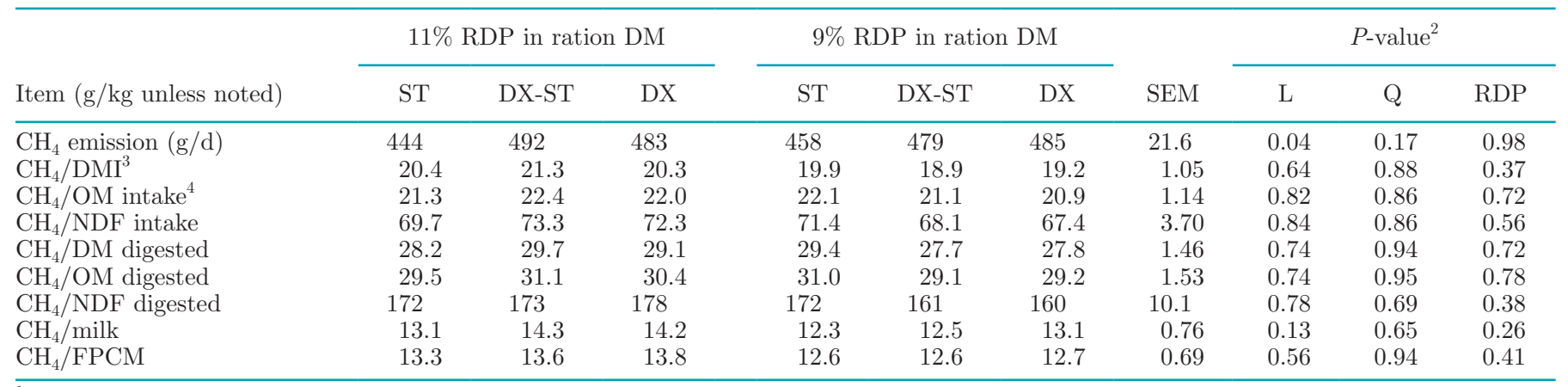

${ }^{1} \mathrm{ST}=10 \%$ refined starch and $0 \%$ dextrose; DX-ST $=5 \%$ refined starch and $5 \%$ dextrose; DX $=0 \%$ refined starch and $10 \%$ dextrose in ration DM.

${ }^{2}$ Main effect of carbohydrate source (ST, DX-ST, or DX) partitioned into linear (L) and quadratic (Q) components and main effect of RDP level. Unless noted in separate footnotes, the interaction between carbohydrate source and RDP level was not significant $(P>0.10)$.

${ }^{3}$ Information on DMI, milk, and fat- and protein-corrected milk (FPCM) was from wk 3, during which $\mathrm{CH}_{4}$ emission was measured.

${ }^{4}$ Information on NDF, OM intake, and amount digested was from wk 4 of each period, during which urine and feces samplings from each cow were conducted. 
Table 5. Linear effects of molar percentages of ruminal VFA on methane production $(\mathrm{n}=54)^{1}$

\begin{tabular}{lcclc}
\hline Independent variable & Minimum & Maximum & Regression $^{2}$ & $P_{\text {-value }}{ }^{3}$ \\
\hline Acetate $(\mathrm{mol} / 100 \mathrm{~mol})$ & 47.9 & 68.5 & $\mathrm{Y}=358+1.88( \pm 2.57) \mathrm{X}$ & 0.47 \\
Propionate $(\mathrm{mol} / 100 \mathrm{~mol})$ & 12.7 & 29.7 & $\mathrm{Y}=603-7.05( \pm 2.76) \mathrm{X}$ & 0.02 \\
Butyrate $(\mathrm{mol} / 100 \mathrm{~mol})$ & 11.3 & 22.3 & $\mathrm{Y}=354+7.28( \pm 3.44) \mathrm{X}$ & 0.04 \\
\hline
\end{tabular}

${ }^{1}$ Linear regression from mixed model predicting methane $(\mathrm{g} / \mathrm{d})$ from shown independent variable after accounting for the random effects of cow and period.

${ }^{2} \mathrm{Y}=$ methane production $(\mathrm{g} / \mathrm{d}) ; \mathrm{X}=$ independent variable. Values in parentheses are $\mathrm{SE}$.

${ }^{3} P$-value of the slope. Slopes were not significant $(P>0.1)$ for valerate and other minor branched-chain VFA (isobutyrate + isovalerate +2 -methylbutyrate).

Effects of Time Relative to Feeding. In this study, cows were fed once a day and the average hourly rate of $\mathrm{CH}_{4}$ emission remained stable with time after feeding except for a decline for the time point $1.5 \mathrm{~h}$ before delivery of a freshly mixed ration in the morning. Overall, the hourly rate of emission was $20.1 \mathrm{~g} / \mathrm{h}$, but it decreased to $15.9 \mathrm{~g} / \mathrm{h}$ at $22.5 \mathrm{~h}$ after feeding time point (Figure 1). Fluctuation in $\mathrm{CH}_{4}$ emission rate was reported to correspond to substrate supply (Mathers and Walters, 1982) and thus pattern of meal consumption. As observed here, the lowest rate of $\mathrm{CH}_{4}$ emission has been reported for measurements conducted before the first feeding in the morning (Aguerre et al., 2011; Laubach et al., 2013). Thus, under the conditions of the present study, it is likely that cows were consuming meals at time intervals fairly equally distributed throughout the feeding cycle, which in turn may explain the absence of large variations in the hourly rate of $\mathrm{CH}_{4}$ emission.

\section{Nutrient Apparent Digestibility}

Measurement of apparent digestibility was conducted in wk 4 of each period, and results are presented in Table 6. Replacing refined starch with dextrose resulted in linear increases in DMI, and thus the nutrients stayed constant as a percentage of ration DM (i.e., OM, CP, and NDF; Table 1), with a tendency for quadratic responses as there was almost no numerical difference between the values observed at the 5 and $10 \%$ substitution rate (DX-ST vs. DX diet) for each of these nutrients. The magnitude of increase in the intake of these nutrients was dependent in part on the tendency $(P=0.09)$ for source of NFC $\times$ level of RDP interaction, as noted in Table 2. As expected, starch intake was reduced when cows were fed the DX diet, with average intake of 5.99, 5.72 , and $5.35 \mathrm{~kg} / \mathrm{d}$ for the ST, DX-ST, and DX treatments, respectively. The amount of $\mathrm{DM}, \mathrm{OM}$, and $\mathrm{CP}$ apparently digested in the total digestive tract followed

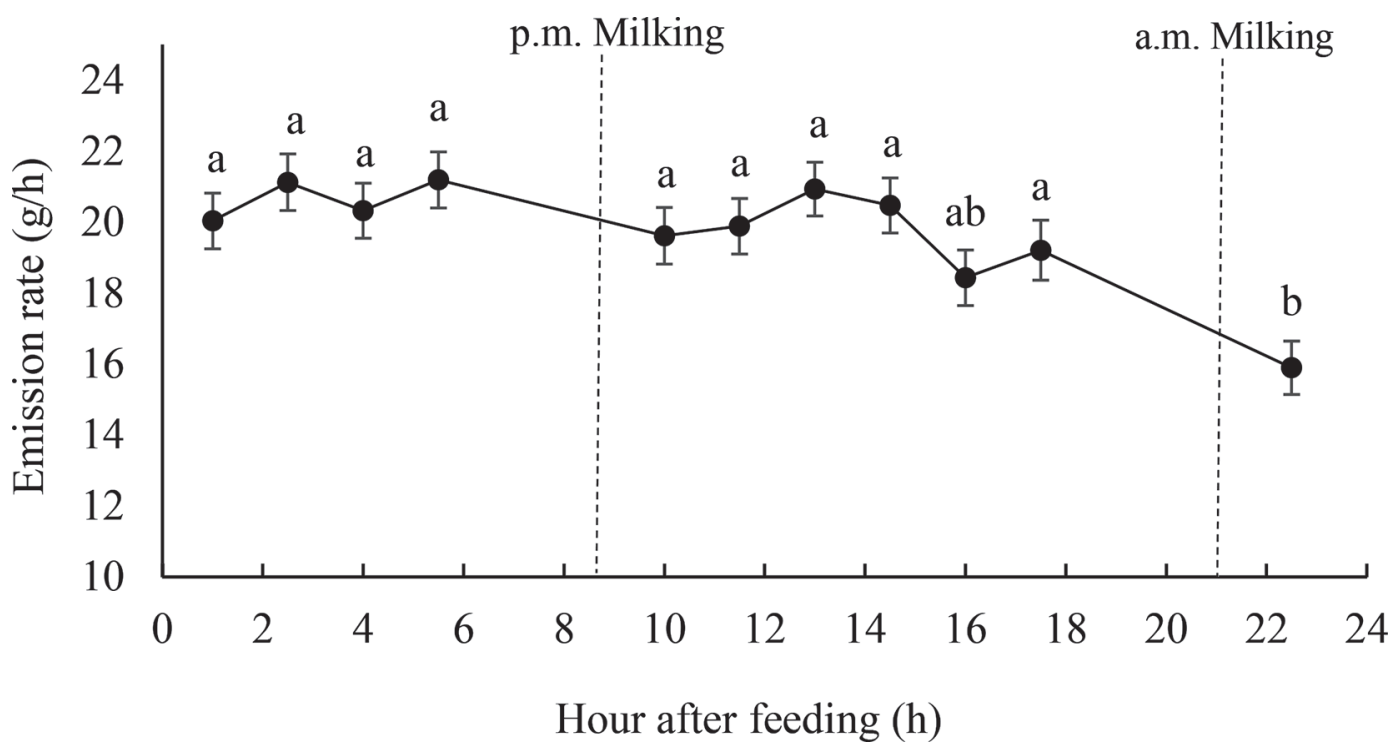

Figure 1. Overall effects of hour after feeding on hourly methane emission rate (all diets combined; 54 observations per time point). Data points without a common superscript $(\mathrm{a}, \mathrm{b})$ differ $(P \leq 0.05)$. Vertical bars represent SE. 
Table 6. Effect of dietary treatments on nutrient intake, nutrient apparently digested, and apparent total-tract digestibility ${ }^{1}$

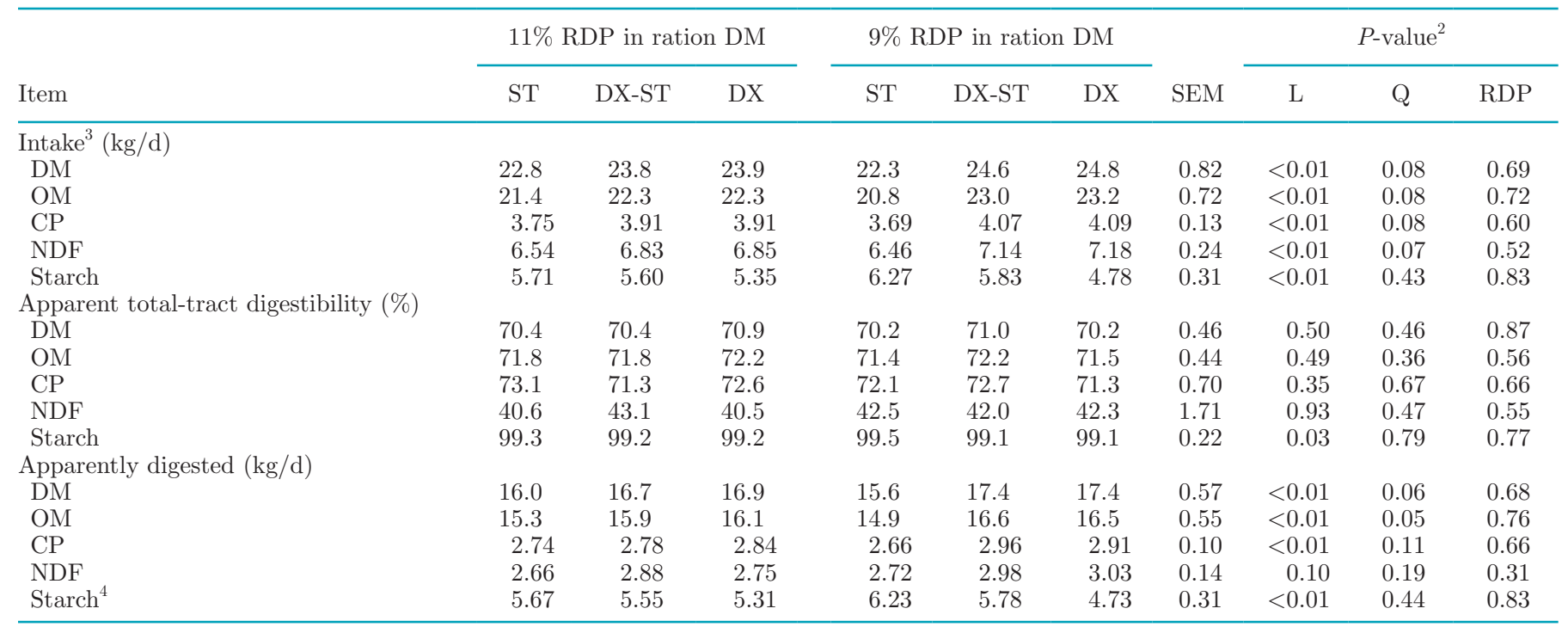

${ }^{1} \mathrm{ST}=10 \%$ refined starch and $0 \%$ dextrose; DX-ST $=5 \%$ refined starch and $5 \%$ dextrose; DX $=0 \%$ refined starch and $10 \%$ dextrose in ration DM.

${ }^{2}$ Main effect of carbohydrate source (ST, DX-ST, or DX) partitioned into linear (L) and quadratic (Q) components and main effect of RDP level. Unless noted in separate footnotes, the interaction between carbohydrate source and RDP level was not significant $(P>0.10)$.

${ }^{3}$ Data were collected from wk 4 of each period.

${ }^{4}$ Carbohydrate source $\times$ RDP level interaction $(P=0.10)$.

the same patterns as described for intake except that the amount of NDF digested remained unaffected by carbohydrate source. Apparent total-tract digestibility of DM, OM, CP, NDF, and starch was 70.5, 71.8, 72.2, 41.8 , and $99.2 \%$, respectively, and remained unaffected by dietary treatments expect that for starch an average decline of 0.2 unit (from $99.4 \%$ to $99.2 \%$ for ST compared with the other 2 diets) was declared significant (Table 6). Gencoglu et al. (2010) also reported high starch digestibility $(>97 \%)$ when cows were offered diets with 21 to $22 \%$ starch (DM basis), and cows consumed a similar amount of starch as observed in our study. The $6.9 \%$ straw in our experimental diets (Table 1) may have contributed to slightly lower apparent digestibility of DM, OM, and NDF reported here than in earlier reports (Reynal and Broderick, 2005; Olmos Colmenero and Broderick, 2006; Gencoglu et al., 2010).

In our study, level of RDP had no effect on intake, amount digested, and percentage of total-tract digestibility for any of the nutrients reported (Table 6). Thus, our data did not support our hypothesis that reduced RDP level would negatively affect NDF digestibility and DMI. Our results, however, agreed with those of Hristov et al. (2004), who reported no differences in ruminal digestibility and total-tract digestibility of DM, $\mathrm{OM}$, and NDF when cows were fed diets with RDP concentration of either 9.4 or $11.6 \%$ (DM basis).

\section{Feces, Urine, Purine Derivatives, N Balance, and N Partition}

Excretion and Composition of Feces and Urine. Replacing refined starch with dextrose resulted in an increase of fecal DM excretion and a tendency for greater $\mathrm{N}$ concentration in fecal DM (Table 7). The greater fecal DM excretion can be attributed to the greater DMI for cows fed the DX diet compared with the ST diet, as total-tract DM digestibility did not differ among dietary treatments. Urine volume averaged $29.5 \mathrm{~L} / \mathrm{d}$, and there was no treatment effect on urinary $\mathrm{N}$ concentration $(0.87 \mathrm{~g} / 100 \mathrm{~mL})$ or urinary urea-N concentration $(0.66 \mathrm{~g} / 100 \mathrm{~mL})$. Level of RDP in the diet did not affect excretion and composition of feces and urine, and data reported in this study were comparable with the values reported in the literature with cows fed diets with similar chemical compositions and production levels (Arndt et al., 2015; Mutsvangwa et al., 2016).

Purine Derivative. Source of carbohydrate influenced in a quadratic fashion the excretion of uric acid $(P=0.01)$, allantoin $(P=0.08)$, and purine derivative $(P=0.04)$, with lower values observed for the DXST diet compared with the ST or the DX diets (Table 7). Furthermore, cows fed the $11 \%$ RDP diets tended to have a greater excretion of purine derivatives than 
those fed the $9 \%$ RDP diets $(493$ vs. $428 \mathrm{mmol} / \mathrm{d} ; P$ $=0.07$ ), an effect primarily due to changes in excretion of allantoin (Table 7). Thus, the data suggested that reducing RDP level to $9 \%$ of dietary DM likely reduced the supply of microbial protein. However, the urinary purine derivative technique used here may not capture known potential for treatment to influence microbial marker concentration and to overestimate precision (Firkins et al., 2006). Reynal and Broderick (2005) tested the effects of 4 levels of RDP and found a reduction in allantoin, purine derivative excretions, and predicted non-ammonia-N flow from the rumen of cows fed $12.3 \%$ RDP compared with $13.2 \%$ RDP diet but no further reductions when cows were fed diets with 11.7 or $10.6 \%$ RDP.

$N$ Balance. There was no carbohydrate source $\times$ RDP level interaction for any of the measures related to $\mathrm{N}$ balance (all $P>0.28$ ), but $\mathrm{N}$ intake, fecal $\mathrm{N}$, and manure $\mathrm{N}$ increased linearly when replacing refined starch with dextrose in the diet (Table 7). However, dietary treatment did not influence excretions of urinary $\mathrm{N}$ and urinary urea- $\mathrm{N}$ (254 and $193 \mathrm{~g} / \mathrm{d}$, respectively). Because diets were iso-nitrogenous, the change in $\mathrm{N}$ intake was essentially due to the change in DMI (Table 2). In this study, RDP level did not affect $\mathrm{N}$ balance, although others have reported increases in manure $\mathrm{N}$ excretions when RDP level increased (Hristov et al., 2004; Reynal and Broderick, 2005); however, our results agreed with these authors, indicating that RDP level did not alter milk $\mathrm{N}$ (true protein) secretion.

$N$ Partitioning. There was a tendency for an increase in the percentage of urea- $\mathrm{N}$ in total urine $\mathrm{N}$ excreted daily when replacing refined starch with dextrose in the diet $(74.4,75.5$, and $77.5 \%$ for ST, DX-ST, and DX diets, respectively; $P=0.06$; Table 7 ). This observation, along with the lower excretions in fecal $\mathrm{DM}$, fecal $\mathrm{N}$, and manure $\mathrm{N}$, suggested that manure from cows fed the ST diet might have a lower environmental impact compared with the manure of cows fed the DX-ST or DX diets. Percentage of urea- $\mathrm{N}$ in total manure $\mathrm{N}$ excreted averaged $44.8 \%$, which agreed with Tamminga (1992). Nitrogen use efficiency decreased linearly when replacing refined starch with dextrose in the diet and averaged 29.3, 27.5, and $27.0 \%$ when cows were fed the ST, DX-ST, and DX diets, respectively. The higher $\mathrm{N}$ use efficiency achieved by cows fed the

Table 7. Effect of dietary treatments on feces and urine excretion and composition and nitrogen (N) balance ${ }^{1}$

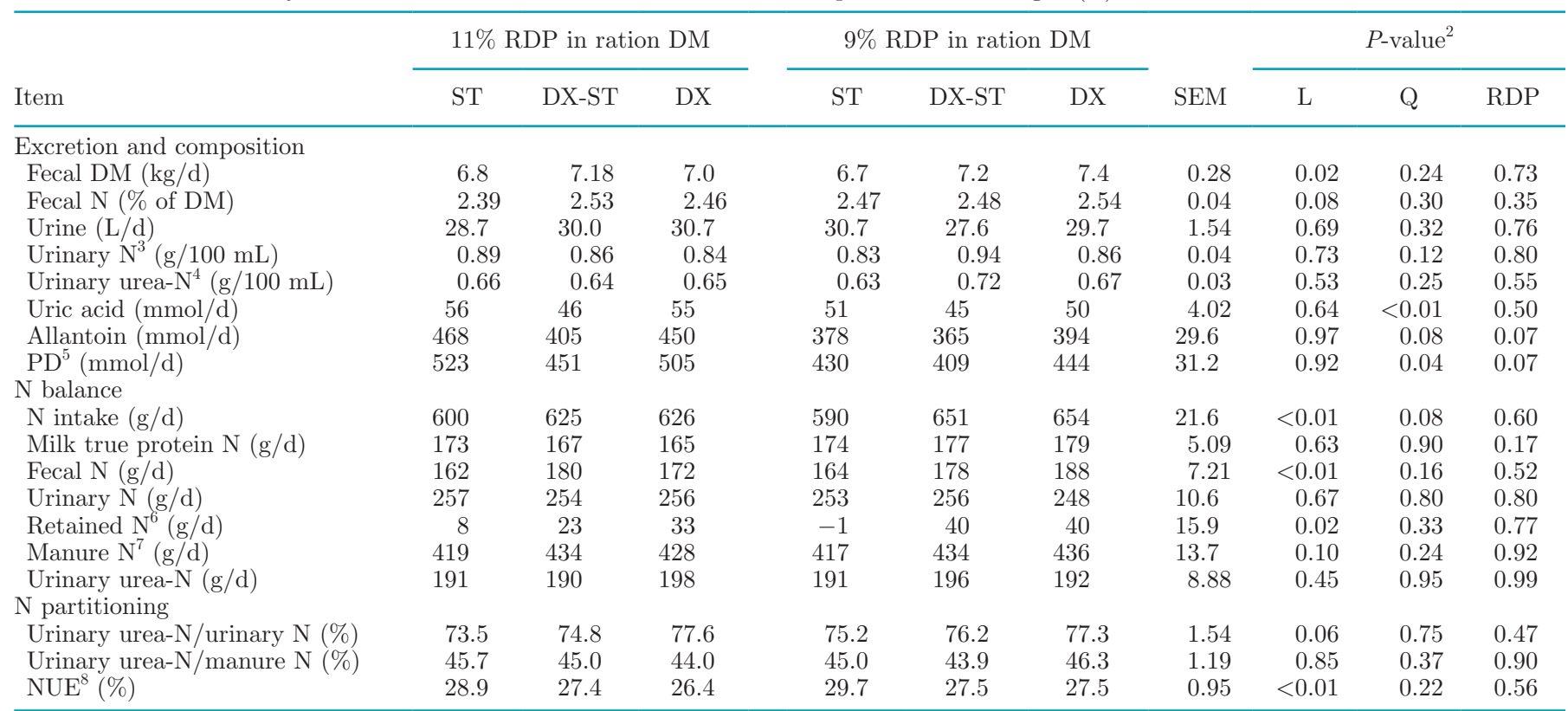

${ }^{1} \mathrm{ST}=10 \%$ refined starch and $0 \%$ dextrose; DX-ST $=5 \%$ refined starch and $5 \%$ dextrose; DX $=0 \%$ refined starch and $10 \%$ dextrose in ration DM.

${ }^{2}$ Main effect of carbohydrate source (ST, DX-ST, or DX) partitioned into linear (L) and quadratic (Q) components and main effect of RDP level. Unless noted in separate footnotes, the interaction between carbohydrate source and RDP level was not significant $(P>0.10)$.

${ }^{3}$ Carbohydrate source $\times$ RDP level interaction $(P=0.06)$.

${ }^{4}$ Carbohydrate source $\times$ RDP level interaction $(P=0.10)$.

${ }^{5}$ Purine derivatives $=$ uric acid + allantoin.

${ }^{6} \mathrm{~N}$ retained $=\mathrm{N}$ intake - milk true protein $\mathrm{N}-$ fecal $\mathrm{N}-$ urinary $\mathrm{N}$.

${ }^{7}$ Manure $\mathrm{N}=$ fecal $\mathrm{N}+$ urinary $\mathrm{N}$.

${ }^{8} \mathrm{~N}$ use efficiency $=$ milk true protein $\mathrm{N} / \mathrm{N}$ intake; data based on $7 \mathrm{~d}$ of $\mathrm{N}$ intake and milk $\mathrm{N}$ in wk 4 of each period. 
ST diet was due to the similar milk true protein yield but lower $\mathrm{N}$ intake compared with cows fed the other 2 diets.

\section{CONCLUSIONS}

Per our main hypothesis, replacing refined starch with dextrose increased enteric $\mathrm{CH}_{4}$ production $(\mathrm{g} / \mathrm{d})$. This effect was due in part to increased DMI and to changes in pattern of ruminal VFA concentration. Under the conditions of this study, enteric $\mathrm{CH}_{4}$ production was negatively related to the molar percentage of propionate and positively related to the molar percentage of butyrate. For the most part, reducing dietary RDP level had no influence on the responses to the source of carbohydrate and did not result in the hypothesized negative effects on DMI, fiber fermentation, and milk performance. However, lower DMI and N intake resulted in greater feed efficiency and conversion efficiency of intake $\mathrm{N}$ into milk protein but lower excretion of fecal $\mathrm{DM}$ and fecal $\mathrm{N}$ for cows fed a diet of $28.1 \%$ starch and $4.6 \%$ water-soluble carbohydrate compared with diets of lower starch and higher water-soluble carbohydrate contents. Thus, under the conditions of this study, the conversion of intake $\mathrm{N}$ into milk protein was influenced by rumen-available carbohydrate source but not RDP level.

\section{ACKNOWLEDGMENTS}

This material was based on work that was supported by the National Institute of Food and Agriculture, US Department of Agriculture (Washington, DC), Coordinated Agricultural Project no. 2013-68002-20525.

\section{REFERENCES}

Aguerre, M. J., M. A. Wattiaux, J. M. Powell, G. A. Broderick, and C. Arndt. 2011. Effect of forage-to-concentrate ratio in dairy cow diets on emission of methane, carbon dioxide, and ammonia, lactation performance, and manure excretion. J. Dairy Sci. 94:30813093. https://doi.org/10.3168/jds.2010-4011.

Allen, M. S., B. J. Bradford, and M. Oba. 2009. Board-invited review: The hepatic oxidation theory of the control of feed intake and its application to ruminants. J. Anim. Sci. 87:3317-3334. https://doi .org/10.2527/jas.2009-1779.

Allison, M. J. 1970. Nitrogen metabolism of ruminal microorganisms, Page 456-473 in Physiology of Digestion and Metabolism in the Ruminant. A. T. Phillipson, ed. Oriel Press, Newcastle upon Tyne, UK

AOAC International. 2016. Official Methods of Analysis. 20th ed. AOAC International, Arlington, VA.

Arndt, C., J. M. Powell, M. J. Aguerre, and M. A. Wattiaux. 2015. Performance, digestion, nitrogen balance, and emission of manure ammonia, enteric methane, and carbon dioxide in lactating cows fed diets with varying alfalfa silage-to-corn silage ratios. J. Dairy Sci. 98:418-430. https://doi.org/10.3168/jds.2014-8298.

Bannink, A., J. France, S. Lopez, W. J. J. Gerrits, E. Kebreab, S. Tamminga, and J. Dijkstra. 2008. Modelling the implications of feeding strategy on rumen fermentation and functioning of the rumen wall. Anim. Feed Sci. Technol. 143:3-26. https://doi.org/10 .1016/j.anifeedsci.2007.05.002.

Barros, T., M. A. Quaassdorff, M. J. Aguerre, J. J. O. Colmenero, S. J. Bertics, P. M. Crump, and M. A. Wattiaux. 2017. Effects of dietary crude protein concentration on late-lactation dairy cow performance and indicators of nitrogen utilization. J. Dairy Sci. 100:5434-5448. https://doi.org/10.3168/jds.2016-11917.

Broderick, G. A., N. D. Luchini, S. M. Reynal, G. A. Varga, and V. A. Ishler. 2008. Effect on production of replacing dietary starch with sucrose in lactating dairy cows. J. Dairy Sci. 91:4801-4810. https: //doi.org/10.3168/jds.2008-1480.

Broderick, G. A., and W. J. Radloff. 2004. Effect of molasses supplementation on the production of lactating dairy cows fed diets based on alfalfa and corn silage. J. Dairy Sci. 87:2997-3009. https: //doi.org/10.3168/jds.S0022-0302(04)73431-1.

Chaney, A. L., and E. P. Marbach. 1962. Modified reagents for determination of urea and ammonia. Clin. Chem. 8:130-132.

Chen, X. B., and M. J. Gomes. 1992. Estimation of Microbial Protein Supply to Sheep and Cattle Based on Urinary Excretion of Purine Derivatives-An Overview of the Technical Details. Int. Feed Resources Unit, Rowett Research Institute, Aberdeen, UK.

Cochran, R. C., D. C. Adams, J. D. Wallace, and M. L. Galyean. 1986. Predicting digestibility of different diets with internal markers: Evaluation of four potential markers. J. Anim. Sci. 63:1476-1483.

Deriaz, R. E. 1961. Routine analysis of carbohydrates and lignin in herbage. J. Sci. Food Agric. 12:152-160.

Dijkstra, J., O. Oenema, and A. Bannink. 2011. Dietary strategies to reducing $\mathrm{N}$ excretion from cattle: Implications for methane emissions. Curr. Opin. Environ. Sustain. 3:414-422. https://doi.org/10 .1016/j.cosust.2011.07.008.

Dorich, C. D., R. K. Varner, A. B. D. Pereira, R. Martineau, K. J. Soder, and A. F. Brito. 2015. Short communication: Use of a portable, automated, open-circuit gas quantification system and the sulfur hexafluoride tracer technique for measuring enteric methane emissions in Holstein cows fed ad libitum or restricted. J. Dairy Sci. 98:2676-2681. https://doi.org/10.3168/jds.2014-8348.

Firkins, J. L., A. N. Hristov, M. B. Hall, G. A. Varga, and N. R. StPierre. 2006. Integration of ruminal metabolism in dairy cattle. J. Dairy Sci. 89(E-Suppl.):E31-E51. https://doi.org/10.3168/jds .S0022-0302(06)72362-1.

Gao, X., and M. Oba. 2016. Effect of increasing dietary nonfiber carbohydrate with starch, sucrose, or lactose on rumen fermentation and productivity of lactating dairy cows. J. Dairy Sci. 99:291-300. https://doi.org/10.3168/jds.2015-9871.

Gencoglu, H., R. D. Shaver, W. Steinberg, J. Ensink, L. F. Ferraretto, S. J. Bertics, J. C. Lopes, and M. S. Akins. 2010. Effect of feeding a reduced-starch diet with or without amylase addition on lactation performance in dairy cows. J. Dairy Sci. 93:723-732. https:// doi.org/10.3168/jds.2009-2673.

Hall, M. B. 2013. Dietary starch source and protein degradability in diets containing sucrose: Effects on ruminal measures and proposed mechanism for degradable protein effects. J. Dairy Sci. 96:7093-7109. https://doi.org/10.3168/jds.2012-5663.

Hall, M. B., C. C. Larson, and C. J. Wilcox. 2010. Carbohydrate source and protein degradability alter lactation, ruminal and blood measures. J. Dairy Sci. 93:311-322. https://doi.org/10.3168/jds $.2009-2552$.

Hatew, B., S. C. Podesta, H. Van Laar, W. F. Pellikaan, J. L. Ellis, J. Dijkstra, and A. Bannink. 2015. Effects of dietary starch content and rate of fermentation on methane production in lactating dairy cows. J. Dairy Sci. 98:486-499. https://doi.org/10.3168/jds.2014 $-8427$.

Hindrichsen, I. K., H. R. Wettstein, A. Machmüller, B. Jörg, and M. Kreuzer. 2005. Effect of the carbohydrate composition of feed concentrates on methane emission from dairy cows and their slurry. Environ. Monit. Assess. 107:329-350. https://doi.org/10.1007/ s10661-005-3008-3.

Hristov, A. N., R. P. Etter, J. K. Ropp, and K. L. Grandeen. 2004. Effect of dietary crude protein level and degradability on ruminal fermentation and nitrogen utilization in lactating dairy 
cows. J. Anim. Sci. 82:3219-3229. https://doi.org/10.2527/2004 82113219x.

Huhtanen, P., K. Kaustell, and S. Jaakkola. 1994. The use of internal markers to predict total digestibility and duodenal flow of nutrients in cattle given six different diets. Anim. Feed Sci. Technol. 48:211-227. https://doi.org/10.1016/0377-8401(94)90173-2.

IDF (International Dairy Federation). 2015. A Common Carbon Footprint Approach for the Dairy Sector. The IDF Guide to Standard Life Cycle Assessment Methodology. IDF, Brussels, Belgium.

Jarrell, K. F., and M. L. Kalmokoff. 1988. Nutritional requirements of the methanogenic archaebacterial. Can. J. Microbiol. 34:557-576. https://doi.org/10.1139/m88-095.

Kalscheur, K. F., R. L. Baldwin VI, B. P. Glenn, and R. A. Kohn. 2006. Milk production of dairy cows fed differing concentrations of rumen-degraded protein. J. Dairy Sci. 89:249-259. https://doi .org/10.3168/jds.S0022-0302(06)72089-6.

Khezri, A., K. Rezayazdi, M. Danesh. Mesgaran, and M. MoradiSharbabk. 2009. Effect of different rumen-degradable carbohydrates on rumen fermentation, nitrogen metabolism and lactation performance of Holstein dairy cows. Asian-australas. J. Anim. Sci. 22:651-658.

Krause, K. M., D. K. Combs, and K. A. Beauchemin. 2003. Effects of increasing levels of refined cornstarch in the diet of lactating dairy cows on performance and ruminal pH. J. Dairy Sci. 86:1341-1353. https://doi.org/10.3168/jds.S0022-0302(03)73719-9.

Laubach, J., M. Bai, C. S. Pinares-Patiño, F. A. Phillips, T. A. Naylor, G. Molano, E. A. Cardenas, and D. W. T. Griffith. 2013. Accuracy of micrometeorological techniques for detecting a change in methane emissions from a herd of cattle. Agric. For. Meteorol. 176:50-63. https://doi.org/10.1016/j.agrformet.2013.03.006.

Mathers, J. C., and D. E. Walters. 1982. Variation in methane production by sheep fed every two hours. J. Agric. Sci. 98:633-638. https: //doi.org/10.1017/S0021859600054435.

McAllister, T. A., K. J. Cheng, E. K. Okine, and G. W. Mathison. 1996. Dietary, environmental and microbiological aspects of methane production in ruminants. Can. J. Anim. Sci. 76:231-243. https: //doi.org/10.4141/cjas96-035.

Mills, J. A., J. Dijkstra, A. Bannink, S. B. Cammell, E. Kebreab, and J. France. 2001. A mechanistic model of whole-tract digestion and methanogenesis in the lactating dairy cow: Model development, evaluation, and application. J. Anim. Sci. 79:1584-1597. https:// doi.org/10.2527/2001.7961584x.

Moe, P. W., and H. F. Tyrrell. 1979. Methane production in dairy cows. J. Dairy Sci. 62:1583-1586. https://doi.org/10.3168/jds .S0022-0302(79)83465-7.

Moss, A. R., J. P. Jouany, and J. Newbold. 2000. Methane production by ruminants: Its contribution to global warming. Ann. Zootech. 49:231-254. https://doi.org/10.1051/animres:2000119.

Mutsvangwa, T., K. L. Davies, J. J. McKinnon, and D. A. Christensen. 2016. Effects of dietary crude protein and rumen-degradable protein concentrations on urea recycling, nitrogen balance, omasal nutrient flow, and milk production in dairy cows. J. Dairy Sci. 99:6298-6310. https://doi.org/10.3168/jds.2016-10917.

Nombekela, S. W., M. R. Murphy, H. W. Gonyou, and J. I. Marden. 1994. Dietary preferences in early lactation cows as affected by primary tastes and some common feed flavors. J. Dairy Sci. 77:23932399. https://doi.org/10.3168/jds.S0022-0302(94)77182-4.

Nordlund, K. V., and E. F. Garrett. 1994. Rumenocentesis: A technique for the diagnosis of subacute rumen acidosis in dairy herds. Bov. Pract. 28:104.
NRC. 2001. Nutrient Requirements of Dairy Cattle. 7th rev. ed. Natl. Acad. Sci., Washington, DC.

Oba, M. 2011. Review: Effects of feeding sugars on productivity of lactating dairy cows. Can. J. Anim. Sci. 91:37-46. https://doi.org/ 10.4141/CJAS10069.

Olmos Colmenero, J. J., and G. A. Broderick. 2006. Effect of dietary crude protein concentration on milk production and nitrogen utilization in lactating dairy cows. J. Dairy Sci. 89:1704-1712. https:/ /doi.org/10.3168/jds.S0022-0302(06)72238-X.

Oser, B. L. 1965. Hawk's Physiological Chemistry. 14th ed. McGrawHill, New York, NY.

Palarea-Albaladejo, J., J. A. Rooke, I. M. Nevison, and R. J. Dewhurst. 2017. Compositional mixed modeling of methane emissions and ruminal volatile fatty acids from individual cattle and multiple experiments. J. Anim. Sci. 95:2467-2480. https://doi.org/ $10.2527 /$ jas.2016.1339

Ramin, M., and P. Huhtanen. 2013. Development of equations for predicting methane emissions from ruminants. J. Dairy Sci. 96:24762493. https://doi.org/10.3168/jds.2012-6095.

Reynal, S. M., and G. A. Broderick. 2005. Effect of dietary level of rumen-degraded protein on production and nitrogen metabolism in lactating dairy cows. J. Dairy Sci. 88:4045-4064. https://doi .org/10.3168/jds.S0022-0302(05)73090-3.

Santos, F. A. P., J. E. P. Santos, C. B. Theurer, and J. T. Huber. 1998 Effects of rumen-undegradable protein on dairy cow performance: A 12-year literature review. J. Dairy Sci. 81:3182-3213. https://doi .org/10.3168/jds.S0022-0302(98)75884-9.

Tamminga, S. 1992. Nutrition management of dairy cows as a contribution to pollution control. J. Dairy Sci. 75:345-357. https://doi .org/10.3168/jds.S0022-0302(92)77770-4.

Valadares, R. F. D., G. A. Broderick, S. C. Valadares Filho, and M. K. Clayton. 1999. Effect of replacing alfalfa silage with high moisture corn on ruminal protein synthesis estimated from excretion of total purine derivatives. J. Dairy Sci. 82:2686-2696. https://doi.org/10 $.3168 /$ jds.S0022-0302(99)75525-6.

Vallimont, J. E., F. Bargo, T. W. Cassidy, N. D. Luchini, G. A. Broderick, and G. A. Varga. 2004. Effects of replacing dietary starch with sucrose on ruminal fermentation and nitrogen metabolism in continuous culture. J. Dairy Sci. 87:4221-4229. https://doi.org/10 .3168/jds.S0022-0302(04)73567-5.

Vidal, B. C. Jr., K. D. Rausch, M. E. Tumbleson, and V. Singh. 2009. Determining corn germ and pericarp residual starch by acid hydrolysis. Cereal Chem. 86:133-135. https://doi.org/10.1094/ CCHEM-86-2-0133.

Yan, T., R. E. Agnew, F. J. Gordon, and M. G. Porter. 2000. Prediction of methane energy output in dairy and beef cattle offered grass silage-based diets. Livest. Prod. Sci. 64:253-263. https://doi .org/10.1016/S0301-6226(99)00145-1.

Zanton, G. I. 2016. Analysis of production responses to changing crude protein levels in lactating dairy cow diets when evaluated in continuous or change-over experimental designs. J. Dairy Sci. 99:4398-4410. https://doi.org/10.3168/jds.2015-10438.

Zanton, G. I., A. J. Heinrichs, and C. M. Jones. 2013. Short communication: Effects of level of rumen-degradable protein and corn distillers grains in corn silage-based diets on milk production and ruminal fermentation in lactating dairy cows. J. Dairy Sci. 96:4638-4642. https://doi.org/10.3168/jds.2012-6030. 